\title{
Seasonal differences in the vertical profiles of aerosol optical properties over rural Oklahoma
}

\author{
E. Andrews ${ }^{1}$, P. J. Sheridan ${ }^{2}$, and J. A. Ogren ${ }^{2}$ \\ ${ }^{1}$ Cooperative Institute for Research in Environmental Sciences, Mail Box 216, University of Colorado, Boulder, \\ CO 80309, USA \\ ${ }^{2}$ Earth Systems Research Laboratory, National Oceanic and Atmospheric Administration, 325 Broadway, Boulder, \\ CO 80305, USA
}

Received: 30 March 2011 - Published in Atmos. Chem. Phys. Discuss.: 18 April 2011

Revised: 10 August 2011 - Accepted: 21 October 2011 - Published: 27 October 2011

\begin{abstract}
A small airplane made 597 aerosol optical property (light absorption and light scattering) vertical profile measurements over a rural Oklahoma site between March 2000 and December 2007. The aerosol profiles obtained during these $8 \mathrm{yr}$ of measurements suggest significant seasonal differences in aerosol loading (scattering and absorption). The highest amounts of scattering and absorbing aerosol are observed during the summer and the lowest loading occurs during the winter. The relative contribution of aerosol absorption is highest in the winter (i.e., single scattering albedo is lowest in winter), particularly aloft. Aerosol absorption generally decreased with altitude below $\sim 1.5 \mathrm{~km}$ and then was relatively constant or decreased more gradually above that. Aerosol scattering decreased sharply with altitude below $\sim 1.5 \mathrm{~km}$ but, unlike absorption, also decreased at higher altitudes, albeit less sharply. Scattering Ångström exponents suggest that the aerosol was dominated by submicron aerosol during the summer at all altitudes, but that larger particles were present, especially in the spring and winter above $1 \mathrm{~km}$. The seasonal variability observed for aerosol loading is consistent with AERONET aerosol optical depth (AOD) although the AOD values calculated from in situ adjusted to ambient conditions and matching wavelengths are up to a factor of two lower than AERONET AOD values depending on season. The column averaged single scattering albedo derived from in situ airplane measurements are similar in value to the AERONET single scattering albedo inversion product but the seasonal patterns are different - possibly a consequence of the strict constraints on obtaining single scattering albedo from AERONET data. A comparison of extinction Ångström exponent and asymmetry
\end{abstract}

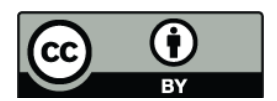

Correspondence to: E. Andrews (betsy.andrews@noaa.gov) parameter from the airplane and AERONET platforms suggests similar seasonal variability with smaller particles observed in the summer and fall and larger particles observed in spring and winter. The observed seasonal cycle of aerosol loading corresponds with changes in air mass back trajectories: the aerosol scattering was higher when transport was from polluted areas (e.g., the Gulf Coast) and lower when the air came from cleaner regions and/or the upper atmosphere.

\section{Introduction}

Understanding the temporal and spatial variability of aerosol optical properties is important for relating aerosols to their sources, quantifying the effects of transport and transformation on the aerosol and understanding the contribution of aerosol to such wide-ranging concerns as health, visibility and climate. The vertical variability of aerosol particles in the atmosphere is an aspect of aerosol spatial distribution that has been less well studied than the horizontal variability, in large part because it is more difficult to sample aloft than from a ground-based platform. Haywood and Ramaswamy (1998) observe that the magnitude and sign of aerosol radiative forcing are partly determined by the vertical distribution of the aerosol. More recently it has been shown that errors in the assumptions about the shape of aerosol profiles can cause errors in aerosol optical thickness retrieved from satellites (Rozwadowska, 2007). Of particular interest for climate change is the question of the vertical distribution of absorbing aerosol in the atmosphere (e.g., Haywood and Ramaswamy, 1998; Ramanathan et al., 2001). Ramanathan et al. (2001) showed that the vertical profile of absorbing aerosol could influence cloud formation and lifetime. Haywood and Ramaswamy (1998) showed that the

Published by Copernicus Publications on behalf of the European Geosciences Union. 
atmospheric aerosol profiles could change calculated direct radiative forcing. Recent modeling studies utilizing a small number (55) of vertical black carbon (BC) aerosol profiles from multiple field campaigns at various locations have met with limited success (e.g., Koch et al., 2009; Vignati et al., 2010) due perhaps to coarse temporal resolution of the comparisons ( 2 to 10 measured profiles were compared with the modeled monthly means for the month the profiles were obtained) or to an oversimplified algorithm for describing transport and transformation of the black carbon. More recent model/measurement comparisons (Skeie et al., 2011) continue to suggest our ability to measure and/or model absorbing aerosol in the atmosphere needs improvement. These model/measurement comparison papers focused on absorbing aerosol and did not discuss how measured in situ aerosol scattering profiles compared with model results.

Lidar provides an alternative to in situ vertical profiling and can provide insight into the vertical loading and variability of aerosol particles; however, deriving profiles of aerosol absorption or other properties (e.g., single scattering albedo, asymmetry parameter) useful for radiative forcing calculations from lidar measurements is still in its infancy (e.g., Veselovskii et al., 2005; Müller et al., 2001). Measurements from ground-based sun-sky radiometers can be inverted to obtain aerosol size distributions, single scattering albedo, and asymmetry parameter (Dubovik and King, 2000; O'Neill et al., 2003) but these retrievals are representative of the atmospheric column rather than any specific location aloft and are typically limited to clear sky conditions.

While in situ aerosol aircraft profiling has often been used for short field campaigns in the last three decades (e.g., Husar et al., 1977; Kim et al., 1988; Li et al., 1997; Osborne and Haywood, 2005; references in Koch et al., 2009), it can also be a relatively inexpensive method to measure aerosol properties in the vertical over the long term using a dedicated light aircraft. University of Maryland made summertime aerosol and gas phase profiling measurements in a small airplane at various locations on the east coast of the US between 1997 and 2003, with a focus on pollution events and air quality (e.g, Taubman et al., 2006; Hains et al., 2008). The University of Maryland program lasted over $6 \mathrm{yr}$, however flights were primarily flown in the summer so analysis of the annual cycle is not possible with their data set. In contrast, NOAA and Department of Energy/Atmospheric Radiation Measurement (DOE/ARM) developed a light aircraft-based aerosol profiling platform for year-round, long term measurements of climatically important aerosol properties. This platform was implemented at the DOE site in Oklahoma (e.g., Andrews et al., 2004) and a similar platform also operated over a NOAA surface site in central Illinois between 2006-2009 (Sheridan et al., 2011). The DOE airplane measured climatically relevant in situ aerosol property profiles between 2000 and 2007. This unique data set spanning eight years and consisting of 597 in situ aerosol vertical profiles is reported on here.
Here we address the following scientific questions using measurements made by DOE's In situ Aerosol Profiles (IAP) airplane:

- Are there seasonal differences in vertical profiles of aerosol properties?

- Are the seasonal trends consistent with other aerosol measurements?

- Do these differences correspond with source region/transport?

\section{Experimental approach}

Profiling flight measurements were conducted over DOE's Southern Great Plains (SGP) site near Lamont, Oklahoma $\left(36.6^{\circ} \mathrm{N}, 97.5^{\circ} \mathrm{W}, 315 \mathrm{~m}\right.$ above sea level; a.s.1.). The site is in north central Oklahoma, making it a location relatively remote from large sources of anthropogenic pollution. The three nearest large cities (Wichita, KS, Tulsa, OK, and Oklahoma City, OK) are all more than $100 \mathrm{~km}$ away. The airborne aerosol optical measurements reported here began March 2000 and observations from the first $2 \mathrm{yr}$ of airborne measurements (253 flights) have been described previously (Andrews et al., 2004). Here, with a longer data set covering $8 \mathrm{yr}$ and 597 profile flights, the seasonal variability of the aerosol optical property profiles is explored. This longer data set allows an exploration of similarities and differences with the previously published vertical profiles, particularly after some platform and payload improvements in 2005 and 2006. The aerosol profiling program ended in December 2007, although the plane is still making vertical profile flights of gas phase components (ozone, carbon cycle gases) over the SGP site.

\subsection{In situ aerosol measurements}

The aerosol system on the IAP aircraft has been described in detail elsewhere (Andrews et al., 2004) so only a brief description is given here. The airplane, a Cessna 172XP, was originally instrumented with an integrating nephelometer (TSI-3563, three-wavelength $(\lambda=450,550$ and $700 \mathrm{~nm})$, total and hemispheric-backscatter capabilities) and a filterbased light absorption instrument (Radiance Research Particle Soot Absorption Photometer (PSAP), $(\lambda=565 \mathrm{~nm}$ adjusted to $550 \mathrm{~nm}$ ). A heater upstream of the instrumentation ensured that measurements were made at low relative humidity $(\mathrm{RH})$ conditions $(\mathrm{RH}<40 \%)$; the aerosol inlet ensured that only sub-micrometer aerosol were measured. In summer 2005 the airplane was upgraded to a Cessna 206 with the capability of flying to higher altitudes. At this time the aerosol inlet was changed to the shrouded inlet design described by Clarke et al. (2004) and McNaughton et al. (2007). The cut size for this inlet on the Cessna 206 has been estimated to be 
approximately $7 \mu \mathrm{m}$, while calculations of particle removal in the tubing downstream of the inlet suggests $5 \mu \mathrm{m}$ particles are passed with $50 \%$ efficiency to the instrument package (Sheridan et al., 2011). In March 2006 the PSAP was upgraded to a 3-wavelength instrument $(\lambda=467,530,660 \mathrm{~nm})$, resulting in almost $2 \mathrm{yr}$ of vertical profiles of spectral absorption. Ambient temperature and relative humidity were also measured utilizing a Vaisala Humicap sensor mounted on the outside of the aircraft.

The airplane flew 1-3 profiles per week during daylight hours. For the first $6 \mathrm{yr}$ of the program, the profile pattern consisted of a 9 level stair-step descent from $\sim 3700$ m a.s.l. down to $\sim 460$ ma.s.l. (flight levels at $3657,3048,2438$, 1828, 1524, 1219, 914, 610 and 457 ma.s.l.). The plane spent approximately $10 \mathrm{~min}$ in level flight at the four highest levels and then $5 \mathrm{~min}$ at each of the five lower levels. After the airplane upgrade in August 2005 an additional flight level at $4575 \mathrm{~m}$ was added; the plane flew at this altitude for 10 min. Between March 2000-June 2005, 628 flights were flown corresponding to $\sim 2.24$ flights/week, however due to system troubleshooting, issues with air traffic control and weather only 458 flights included all 9 flight levels. Between September 2005 and December 2007, 182 flights were flown, corresponding to $\sim 1.5$ flights/week. Again instrument trouble-shooting, weather and some different flight plans for non-aerosol instrumentation resulted in 139 complete aerosol profile flights (i.e., flights with all 10 flight levels). Table 1 lists the monthly and seasonal breakdown of the flight data for the 458 complete flights flown between March 2000 and June 2005 and the 139 complete flights between September 2005 and December 2007. Figure 1 is a time series contour plot of aerosol light scattering as a function of altitude for the entire time period. The black dots indicate individual flight levels and demonstrate there was little temporal bias in flight coverage. The seasonal oscillation of flight level altitudes occurs because the pilot flies at fixed pressure altitudes, not geometric altitudes.

The measurements were subjected to a set of standard adjustments and corrections. The absorption measurements were adjusted for instrument artifacts (e.g., filter spot size and flow) and interference by scattering aerosol deposited on the filter following the method described in Bond et al. (1999) with the modifications described by Ogren (2010) for the 3-wavelength version of the instrument. The nephelometer light scattering measurements were corrected for instrument non-idealities (e.g., truncation angle) based on work by Anderson and Ogren (1998). The measurements are reported at standard temperature and pressure (STP), $T_{\text {standard }}=0{ }^{\circ} \mathrm{C}$ and $P_{\text {standard }}=1013.25 \mathrm{hPa}$.

From the measured aerosol absorption $\left(\sigma_{\mathrm{ap}}\right)$, scattering $\left(\sigma_{\mathrm{sp}}\right)$ and backscattering $\left(\sigma_{\mathrm{bsp}}\right)$ coefficients, several climatically important aerosol optical parameters can be calculated. These include: single scattering albedo $\omega_{o}=\sigma_{\mathrm{sp}} /\left(\sigma_{\mathrm{sp}}+\sigma_{\mathrm{ap}}\right)$; scattering Ångström exponent $\stackrel{\circ}{\mathrm{sp}}=-\log \left(\sigma_{\mathrm{sp}, \mathrm{i}} /\left(\sigma_{\mathrm{sp}, \mathrm{j}}\right) / \log \left(\lambda_{i} /\left(\lambda_{j}\right) ;\right.\right.$ absorption Ångström

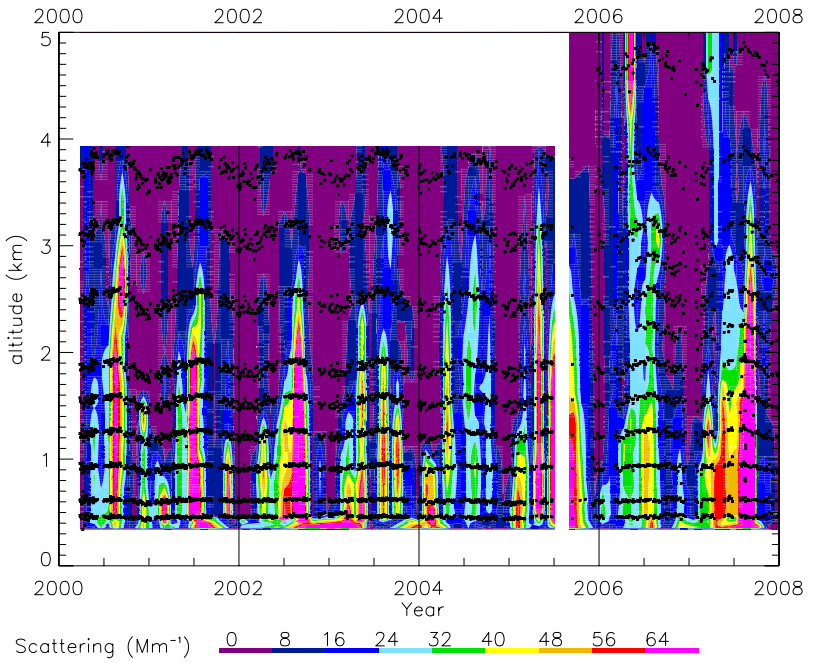

Fig. 1. Contour time series showing aerosol light scattering in terms of fractional year and altitude for the $8 \mathrm{yr}$ of airplane measurements. Gap in the time series around 2005.5 was during the upgrade to a new airplane and inlet. Black dots on figure indicate individual flight segments from the 597 flights flown between 2000-2007.

exponent $\left(\stackrel{\circ}{a p}_{\text {ap }}\right.$ ), analogous to the scattering Ångström exponent, but here we applied a power law fit to the spectral absorption: $\sigma_{\mathrm{ap}, \lambda} \sim(\lambda)^{- \text {åap }}$ (Moosmüller et al., 2009); and asymmetry parameter, estimated with the empirical relationship $g=-7.1439 b^{3}+7.4644 b^{2}-3.9636 b+0.9893$, where $b$ is the ratio of hemispheric backscattering to total backscattering $\left(\sigma_{\mathrm{bsp}} / \sigma_{\mathrm{sp}}\right)$, also called backscatter fraction (Andrews et al., 2006). Additionally, for qualitative comparison with model output and chemical measurements, equivalent black carbon (EBC) concentrations were derived from light absorption measurements made by the PSAP assuming that all light absorption was caused by black carbon with a mass absorption coefficient of $7.5 \mathrm{~m}^{2} \mathrm{~g}^{-1}$ at $550 \mathrm{~nm}$ wavelength (as recommended by Bond and Bergstrom (2006) for fresh black carbon). We call this EBC because if the aerosol absorption was caused by other species, such as organic carbon or dust, or if aging influenced the optical properties of the absorbing aerosol then the value of $7.5 \mathrm{~m}^{2} \mathrm{~g}^{-1}$ would be inappropriate (Bond and Bergstrom, 2006).

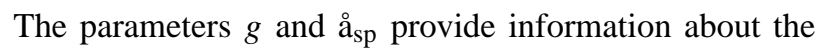
size distribution of the aerosol particles in an air mass. Asymmetry parameter is derived from backscatter fraction, which provides information about the small end of the size distribution, while scattering Ångström exponents are used to identify the presence or absence of large aerosol particles such as dust or sea-salt. The meaning of the scattering Ångström exponent changes depending on the shape of the size distribution. If the size distribution is mono-modal, then a "smaller" åsp means a decrease in particle size. If the size distribution is bimodal, then "smaller" $\stackrel{\circ}{s p}_{\text {means that }}$ 
Table 1. Temporal statistics for 458 complete profile flights between March 2000 and June $2005^{*}$ and 139 complete profile flights between September 2005 and December 2007.

\begin{tabular}{|c|c|c|c|c|}
\hline \multirow[b]{2}{*}{ Season } & \multicolumn{2}{|c|}{$3 / 2000-7 / 2005$} & \multicolumn{2}{|c|}{$9 / 2005-12 / 2007$} \\
\hline & \#flights/season & \#flights/month & \#flights/season & \#flights/month \\
\hline \multirow[t]{3}{*}{ Spring } & 135 & 41 (March) & 25 & 11 (March) \\
\hline & & 31 (April) & & 8 (April) \\
\hline & & 63 (May) & & 6 (May) \\
\hline \multirow[t]{3}{*}{ Summer } & 111 & 23 (June) & 35 & 11 (June) \\
\hline & & 42 (July) & & 10 (July) \\
\hline & & 46 (August) & & 14 (August) \\
\hline \multirow[t]{3}{*}{ Fall } & 105 & 38 (September) & 48 & 15 (September) \\
\hline & & 32 (October) & & 17 (October) \\
\hline & & 35 (November) & & 16 (November) \\
\hline \multirow[t]{3}{*}{ Winter } & 107 & 35 (December) & 31 & 16 (December) \\
\hline & & 37 (January) & & 8 (January) \\
\hline & & 35 (February) & & 7 (February) \\
\hline
\end{tabular}

* Only flights over the SGP CART site with all 9 (10) level legs are included in this table.

the fine mode contributes relatively more scattering than the coarse mode. Discussion in Collaud Coen et al. (2007) suggests that, for the wavelengths discussed here, the backscatter fraction and, hence, $g$ is most sensitive to the smallest accumulation mode particles, i.e., diameter $<0.4 \mu \mathrm{m}$, while $\mathrm{a}_{\mathrm{sp}}$ is most sensitive to particles in the $0.5-0.8 \mu \mathrm{m}$ diameter range (see their Fig. 7). Thus changes in these two parameters reflect changes in different parts of the size distribution and, depending on the shape of the aerosol size distribution, can vary independently.

The calculation of uncertainties for the nephelometer and PSAP measurements as a function of averaging time and loading are described in Sheridan et al. (2002) and references therein. The uncertainties are important when looking at measurements made for low loading conditions as was frequently the case for many of the higher altitude flight legs. Aerosol optical parameters are calculated for 4 representative cases (high scattering, 5 min averages (representative of summertime measurements at the surface); low scattering, 5 min averages (representative of wintertime measurements at the surface); high scattering, $10 \mathrm{~min}$ averages (representative of summertime measurements aloft) and low scattering, $10 \mathrm{~min}$ averages (representative of wintertime measurements aloft). These calculations are presented in Table 2 and referenced in the discussion of the observed profile results.

\subsection{AERONET measurements}

AERONET sun photometer measurements have been made at the SGP surface site since 1994. Because we are focused on comparing the aerosol seasonal climatology from AERONET and the in situ profiles rather than a flight-byflight comparison, the entire available AERONET data set
Table 2. Representative uncertainty measurements.

\begin{tabular}{lllll}
\hline Variable & $\begin{array}{l}\operatorname{high}^{1} \sigma_{\mathrm{sp}}, \\
5 \mathrm{~min}\end{array}$ & $\begin{array}{l}\text { high }^{2} \sigma_{\mathrm{sp}}, \\
10 \mathrm{~min}\end{array}$ & $\begin{array}{l}\text { low } \\
5 \mathrm{~min}\end{array}$ & $\begin{array}{l}\text { low } \sigma_{\mathrm{sp}}, \\
10 \mathrm{~min}\end{array}$ \\
\hline$\sigma_{\mathrm{sp}}$ & 3.85 & 1.17 & 2.31 & 0.41 \\
$\sigma_{\mathrm{ap}}$ & 0.65 & 0.26 & 0.29 & 0.21 \\
$\omega_{o}$ & 0.01 & 0.02 & 0.01 & 0.04 \\
$\stackrel{\mathrm{a}}{\mathrm{sp}}_{\mathrm{a}}$ & 0.45 & 0.45 & 0.45 & 0.47 \\
$\mathrm{a}_{\mathrm{ap}}$ & 1.41 & 2.1 & 1.86 & 4.50 \\
$g$ & 0.25 & 0.48 & 0.29 & 1.49 \\
\hline
\end{tabular}

${ }^{1} \sigma_{\mathrm{sp}}=50 \mathrm{Mm}^{-1} ;{ }^{2} \sigma_{\mathrm{sp}}=20 \mathrm{Mm}^{-1} ;{ }^{3} \sigma_{\mathrm{sp}}=30 \mathrm{Mm}^{-1} ;{ }^{4} \sigma_{\mathrm{sp}}=5 \mathrm{Mm}^{-1}$

(1994-2011) of "Level 2.0" aerosol optical depth (AOD) and Ångström exponent and Level 2.0 almucantar inversion products were downloaded from the AERONET site (http://aeronet.gsfc.nasa.gov). Michalsky et al. (2010), utilizing a different set of long term radiometric measurements, noted no long term trend in AOD at the SGP site over the time period from 1992-2008; thus utilizing the long term AERONET data set is unlikely to bias the comparisons described here. The almucantar inversion products include column-average $\omega_{o}$ and $g$ and information about the aerosol size distribution (Dubovik and King, 2000; O'Neill et al., 2003). The aerosol properties obtained from AERONET differ in wavelength, altitude range covered, humidity conditions and particle size cut from those observed using the in situ instruments on the aircraft. Nonetheless, by adjusting the in situ measurements to ambient conditions (i.e., using seasonal estimates of hygroscopic growth from surface measurements; accounting for wavelength differences by using 
an Ångström adjustment for $\sigma_{\mathrm{sp}}$ and $\sigma_{\mathrm{ap}}$; and averaging over the column we can quantitatively compare seasonal medians of column properties derived from the in situ measurements with those for the AERONET data products.

\section{Results and discussion}

There are significant seasonal differences in the profiles of median aerosol optical properties measured over the SGP site (Fig. 2). Figure 2a and b depicts aerosol absorption and scattering at low RH $(<40 \%)$ and STP for both time periods and, thus, both inlet size cuts. Regardless of inlet size cut, more aerosol loading (as indicated by absorption and scattering) is observed during summer than for any other season, while the least amount of aerosol loading is observed in the winter. Additionally, the shapes of the aerosol profiles shown in Fig. 2a and b suggest that increased amounts of aerosol extend higher in the atmosphere in the summer than at other times of year, reflecting changes in the boundary layer height and enhanced vertical mixing in the summer. Near the surface, summertime scattering and absorption are approximately a factor of two higher than the scattering and absorption observed in winter, while at higher altitudes summertime scattering may be a factor of 10 larger than that observed in the winter and summertime absorption may be 34 times larger than the wintertime absorption. Median EBC ranges from a maximum of approximately $250 \mathrm{ng} \mathrm{m}^{-3}$ in the summer at low altitudes $(<1 \mathrm{~km})$ to $100 \mathrm{ng} \mathrm{m}^{-3}$ over the same altitude range in winter. At higher altitudes $(>1.5 \mathrm{~km})$ EBC is less than $100 \mathrm{ng} \mathrm{m}^{-3}$ for all seasons except summer and is less variable with altitude than below $1.5 \mathrm{~km}$. The estimates of EBC in Fig. 2a are somewhat lower than predicted by the work of Park et al. (2003). Park et al. (2003) used a combination of elemental carbon measurements from the Interagency Monitoring of Protected Visual Environments (IMPROVE) network and model simulations to determine the spatial distribution of carbonaceous aerosol concentrations across the US. They suggest concentrations of annual mean elemental carbon in the region to be $400-500 \mathrm{ng} \mathrm{m}^{-3}$. There were no IMPROVE sites in Oklahoma at the time of their study, so the predicted values of EBC in the region of the SGP site were the result of filling the gap in measurements between the eastern and western US.

Figure 2 includes horizontal lines indicating the upper and lower quartile of the summer and winter measurements. The quartiles were of similar magnitude for spring and fall, but are not plotted for graphical clarity. There is little overlap of these seasonal quartile lines for the measured parameters (e.g., absorption, scattering, extinction), but more overlap for the calculated parameters. The Mann-Whitney U-test (Fay and Proschan, 2010) suggests that the differences observed between summer and winter scattering and summer and winter absorption profiles are significant to greater than the 0.99 confidence level. Spring, fall and annual profiles of scattering and absorption are not statistically different from each other at the 0.99 confidence level. These profile plots show that at the highest altitudes very little aerosol is measured. This can lead to outliers in the calculation of derived aerosol properties such as $\omega_{o}$, $\stackrel{a}{s p}_{\text {, }} \stackrel{\circ}{a p}_{\text {ap }}$ and $g$. Here the derived properties are only calculated when the scattering at $550 \mathrm{~nm}$ was greater than $1 \mathrm{Mm}^{-1}$.

The SGP surface site has a variety of ground-based instrumentation for measuring atmospheric extinction. These include Raman lidar, which provides extinction profiles (e.g., Turner et al., 2001) and radiometric measurements which yield column average extinction (AOD) (e.g., Michalsky et al., 2010). As with the in situ aerosol extinction profiles reported here (Fig. 2c), both Michalsky et al. (2010) and Turner et al. (2010) find the highest extinction occurs in the summer and the lowest in winter, with fall and spring in between the summer and winter values. The observed seasonality in extinction is consistent with other measures of aerosol loading in the region, including surface measurements of aerosol optical properties at SGP (Sheridan et al., 2001; Delene and Ogren, 2002). IMPROVE network measurements of aerosol mass in the central US also typically show the most mass during the summer, primarily due to increases in the sulfate aerosol mass (Malm et al., 2004). Malm et al. (2004) suggest that the amount of organic aerosol, another potentially large scatterer, is fairly invariant throughout the year and region. A more direct comparison can be done between the in situ and lidar extinction profiles. Turner et al. (2001) presents seasonal mean vertical profiles of extinction from a Raman lidar as a function of aerosol optical depth (their Fig. 1) so it is difficult to quantitatively compare with the seasonal median vertical profiles presented here; nonetheless, the shapes of the lidar-derived extinction profiles as a function of season are quite similar to those obtained from the in situ airplane profiling. The seasonal variability and general shape of the light extinction profiles derived from the in situ data (Fig. 2c) is also consistent with the eastern United States seasonal average extinction profiles from CALIPSO reported by Yu et al. (2010). The CALIPSO profiles are ambient nighttime extinction measurements made between June 2006-November 2007 over a very large region $\left(\sim 4\right.$ million $\left.\mathrm{km}^{2}\right)$ so a closer comparison with these in situ measurements is inappropriate. A more detailed statistical comparison of seasonal profiles for CALIPSO and these airplane measurements is in progress.

Vertical profiles of $\omega_{o}($ low $\mathrm{RH}<40 \%)$ also vary by season (Fig. 2d), particularly above $1000 \mathrm{~m}$ a.s.l. in the winter. Above $1000 \mathrm{~m}$, the median wintertime $\omega_{o}$ is lower (more absorbing) than at any other time of year and decreases substantially between $1000 \mathrm{~m}$ a.s.l. and $3700 \mathrm{~m}$ a.s.l. This is due to a greater decrease in scattering relative to absorption at these altitudes (Fig. 2ab). In contrast, the spring and summertime $\omega_{o}$ values tend to be higher (i.e., the aerosol is less absorbing) than those observed in winter. Above $1 \mathrm{~km}$, the spring and fall $\omega_{o}$ profiles lie in between the winter and summer profiles 

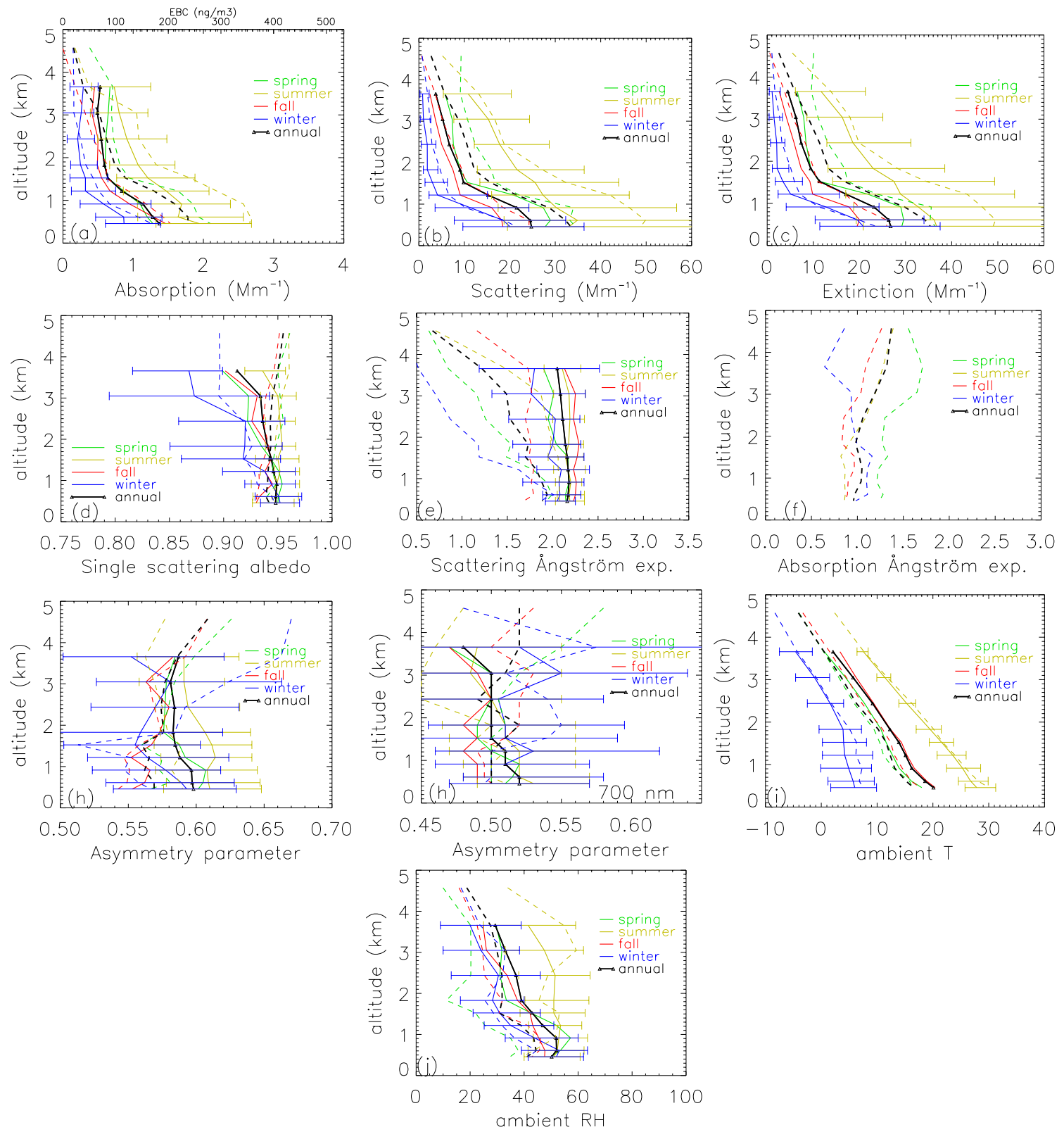

Fig. 2. Vertical profiles of aerosol optical properties and ambient $T /$ RH. Solid lines are for March 2000-June 2005 time period (sub1-micron); dotted lines are for September 2005-Dececember 2007 time period (sub7-micron). Data are at $\mathrm{RH}<40 \%$, wavelength $=550 \mathrm{~nm}$ unless otherwise noted (a) aerosol light absorption; (b) aerosol light scattering (c) aerosol light extinction (d) single scattering albedo (e) scattering Ångström exponent 550/700 nm pair (f) absorption Ångström exponent 467/530/660 fit (g) asymmetry parameter (h) asymmetry parameter $(700 \mathrm{~nm})$ (i) ambient $T$ (j) ambient RH. Horizontal lines indicate 25th and 75th percentiles for winter (blue) and summer (gold) for submicron inlet data. Plots only include complete flights. Single scattering albedo, scattering and absorption Ångström exponents, sub-micron scattering fraction and asymmetry parameter were only calculated for scattering $(550 \mathrm{~nm})>1 \mathrm{Mm}^{-1}$.

and are similar to the annual median $\omega_{o}$ profile. At the lowest flight levels the most absorbing aerosols are observed in fall $\left(\omega_{o} \sim 0.93\right)$, while the $\omega_{o}$ values for the other seasons are quite similar (0.94-0.95). In general, median $\omega_{o}$ values in the lower column $(<1.2 \mathrm{~km})$ agree well with the long term surface value reported for SGP (0.94-0.95) (Delene and Ogren, 2002; Sheridan et al., 2001). The Mann-Whitney U test sug- gests summer and winter $\omega_{o}$ values are different at the 0.99 confidence level above $1.2 \mathrm{~km}$.

The lower $\omega_{o}$ aloft in winter is unlikely to be due to signal to noise issues as increased noise and/or issues with instrument detection limit would not introduce a bias. Uncertainties in single scattering albedo are presented in Table 2. These uncertainties suggest that the decrease in $\omega_{o}$ 
observed here are real and not due to a sampling artifact or noise. The low $\omega_{o}$ aloft in winter may be due to processing of the aerosol during long range transport. As will be discussed later, the winter trajectories tend to descend from high altitude, suggesting the aerosol may be been aloft for some time giving it time to undergo atmospheric processing (e.g., coagulation, condensation, wet and dry scavenging). The effect of cloud scavenging decreasing in situ $\omega_{o}$ values has been previously noted (e.g., Berkowitz et al., 2011; Marcq et al., 2010; Sellegri et al., 2003). Figure 2d also suggests there is a difference in the shapes of the single scattering albedo profiles for the two different time periods. The profiles obtained with the sub7-micron inlet show a constant or slightly increasing $\omega_{o}$ with altitude for all seasons except winter. In contrast, the sub-micron profiles suggest a decrease in $\omega_{o}$ with altitude as was noted in Andrews et al. (2004). A similar decrease in sub-micron $\omega_{o}$ with altitude was observed by Taubman et al. (2006) for 160 summertime sub-micron $\omega_{o}$ profiles obtained from flights over the mid-Atlantic region of the United States. For the SGP profiles, this change in $\omega_{o}$ profile shape for the two time periods could be due to differences in the inlet size cut or to real differences in the aerosol optical properties for the two time periods or to a combination of both; unfortunately the types of measurements that could help determine the cause (e.g., aerosol chemistry, simultaneous measurement of the size dependence of absorption and scattering) are not available.

Figure 2e shows the seasonality of the scattering Ångström exponent (550/700 $\mathrm{nm}$ wavelength pair). This figure demonstrates the importance of inlet size cut in characterizing particles. For the first $6 \mathrm{yr}$, the program only measured submicron aerosol and this is reflected in the Angström exponent values for that time period $-\stackrel{\circ}{s p}_{\text {is typically greater }}$ than 2.0 regardless of season and altitude. Once the inlet was upgraded to allow sampling of super-micron aerosol, the profiles of Ångström exponent exhibit more variability both with altitude and season. Below $1.5 \mathrm{~km}$ the aerosol appears to be dominated by submicron particles regardless of season ( $\stackrel{\circ}{s p}_{\text {> }}$ 1.8). Low values of $\AA_{\mathrm{sp}}$, for the winter and spring profiles suggest a significant presence of larger aerosol at higher altitudes ( $>1.5 \mathrm{~km})$. Again, the calculated uncertainties (Table 2) suggest the low values observed here in spring and winter are unlikely to be due to sampling artifact or noise. The large particle signature in the spring could be due to long range transport of Asian dust aerosol across North America (Augustine et al., 2008; VanCuren and Cahill, 2002). Summertime aerosol still appears to be dominated by sub-micron aerosol as, even with the new inlet, the Angström exponent is $\sim 2.0$ through most of the profile. The fall Angström exponent profile also indicates the primary influence of submicron particles throughout the column.

A climatology of the column average Ångström exponent at the SGP site is consistent with these observations in that it also suggests the smallest particles are observed in summer (Michalsky et al., 2010). While the column average and the vertical profile measurements of Ångström exponent present a consistent picture, measurement climatologies at the surface SGP site show the opposite - both Sheridan et al. (2001) and Delene and Ogren (2002) report smaller Ångström exponents (i.e., larger particles) in the summer than at other times of the year. This discrepancy between surface and profile climatologies is somewhat surprising given the good agreement between scattering measurements made at the surface $(S)$ and the lowest flight leg (LL) (150 m above ground level) (e.g., $\left.\sigma_{\mathrm{sp}, \mathrm{LL}}=1.02 \times \sigma_{\mathrm{sp}, S}+3.73\left(R^{2}=0.94\right)\right)$. However, the relationship between surface and lowest flight level Ångström exponent for the 2005-2007 time period is not as strong:

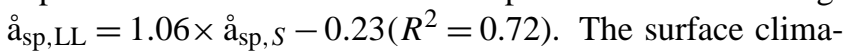
tology may differ due to agricultural activities in the area and/or thermal convection generating super-micron particles (dust/soil) which are not sampled by the airplane measurements.

Absorption Ångström exponent profiles are plotted in Fig. 2f. The values for summer, fall and winter are mostly in the $1.0 \pm 0.2$ range suggesting absorption is dominated by elemental carbon. The median springtime values of absorption Angström exponent are consistently larger than for the

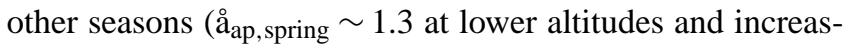
ing up to $\stackrel{\circ}{a p}$,spring $_{2} \sim 1.8$ above $2000 \mathrm{~m}$ ). An increase in $\stackrel{\circ}{a p}$ indicates the presence of species that absorb more strongly at shorter wavelengths than black carbon, which might be associated with dust or with organics from biomass burning (Moosmüller et al., 2009; Kirchstetter et al., 2004). As discussed above, the scattering Ångström exponent (Fig. 2e) profile also supports the possibility of springtime dust transport to the site. Another feature of this plot is that $a_{\text {ap }}$ appears to be relatively constant with altitude up to $\sim 2500 \mathrm{~m}$. Elemental carbon has an absorption Ångström exponent near unity (i.e., $\sigma_{\mathrm{ap}} \sim \lambda^{-1}$ ) based on the assumption of constant index of refraction and particles small relative to the wavelength of light. Bond and Bergstrom (2006) suggest that "constant refractive index for light absorbing carbon at visible wavelengths is consistent with available data". The values lower than 1.0 observed here may be partially explained if the aerosol index of refraction changes slightly with wavelength or the size of the absorbing particles approaches the measurement wavelength. Unfortunately the uncertainties in the $\stackrel{a}{a p}_{\text {c }}$ calculation are larger than the median values of $\stackrel{a}{a p}$ (Table 2) implying that the observed differences are below the detection limits of the instrument.

Asymmetry parameter vertical profiles also show seasonal differences. We have included profile plots of asymmetry parameter for both $550 \mathrm{~nm}$ (Fig. $2 \mathrm{~g}$ ) and $700 \mathrm{~nm}$ (Fig. 2h) wavelengths as they show somewhat different behavior and the $700 \mathrm{~nm}$ wavelength is closer to the wavelength $(673 \mathrm{~nm})$ utilized for the AERONET comparison later in the paper. For both wavelengths, the fall season (and, to some extent, winter) values of $g$ tend indicate enhanced amounts of small $(<0.4 \mu \mathrm{m})$ particles while the trend is the opposite in the summer. This could be due, in part, 
to enhanced gas-to-particle conversion during the warmer summer months. A difference between the profiles for the two wavelengths is that the seasonal dependence of $g$ at $700 \mathrm{~nm}$ is more consistent with the Ångström exponent values (Fig. 2e) (i.e., above $1.5 \mathrm{~km}$ small particles dominate in summer, larger particles in the winter). Again, uncertainty calculations in Table 2 suggest the seasonal and spectral differences in $g$ may be below the detection limits of the instrument.

An interesting feature of the asymmetry profile plots is the shift in $g$ to lower values after the installation of the sub7micron inlet. Several hypotheses might explain this, including: (1) a problem with the sub7-micron inlet preferentially sampling smaller $(<0.4 \mu \mathrm{m})$ particles; alternatively the sub1micron inlet had losses of sub-1-micron aerosol in that size range; (2) the equation used to calculate $g$ is flawed; (3) there was a consistent shift in atmospheric aerosol size distribution before and after the inlet was upgraded to the sub7micron cut size; alternatively the flights in 2005-2007 were somehow biased towards sampling conditions with more accumulation mode particles. We believe we can eliminate (1) based on the detailed characterization of the sub7-micron inlet (Clarke et al., 2004; McNaughton et al., 2007). Point (2) has its merits. For example, Doherty et al. (2005) suggested that changes in backscatter fraction (from which asymmetry parameter is calculated) can also be driven by particle shape and that we may not fully understand the uncertainty associated with corrections applied to the nephelometer data. This suggests that backscattering fraction (and, hence, asymmetry parameter) may not be a robust indicator of particle size, particularly for data at low RH conditions where particle sphericity is not assured. Additionally, Liu et al. (2008) demonstrate the complex relationship between asymmetry parameter, aerosol refractive index, wavelength and Ångström exponent (their Figs. 5 and 7 and related discussion). However, there was excellent agreement between the method utilized here for calculating $g$ and other independent means of calculating the asymmetry parameter, both aloft and at the surface during a field campaign at the SGP site (Andrews et al., 2006). A consistent shift in the size distribution (Point 3) seems unlikely although ambient RH statistics (Fig. 2i) were slightly lower (by $\sim 10 \% \mathrm{RH}$ ) in the 2005-2007 time period than for the 2000-2005 time period, suggesting a slight change in atmospheric conditions. Additionally, there were fewer early morning flights in the 2005-2007 time period than the 2000-2005 period. This may have resulted in a slight sampling bias as the daily cycle of backscatter fraction at the surface shows that $b$ is lower in the morning and increases in the afternoon (Delene and Ogren, 2002). The asymmetry parameter varies inversely with $b$ so this would be consistent with the shift in $g$ observed in Fig. 2gh.

Figure $2 \mathrm{~h}$ and i show ambient temperature and relative humidity from a sensor mounted under the wing (2000$2005)$ or on the airplane fuselage (2005-2007). As would be expected, summer temperatures are consistently higher than those measured in winter (Fig. 2h), with fall and spring temperatures lying close to the annual median value. Both temperature and relative humidity values decrease with altitude with slight kinks indicating seasonal changes in atmospheric structure and boundary layer height. The temperature values for the two time periods are quite similar, although the wintertime temperatures for the second time period are a few degrees warmer at lower altitudes. For both time periods, above $1 \mathrm{~km}$, the summer RH values are higher than the other seasons and the winter RH tends to be lower than the other seasons. The 2005-2007 time period appears to be drier for all seasons consistent with the on-going drought conditions in Oklahoma. In general, the RH values tend to be quite low - median values are less than $60 \%$ while even the upper quartiles of RH in summer are less than $65 \%$ RH. Ferrare et al. (2006) compared the IAP RH measurements with other measurements of water vapor during a short springtime field campaign in 2003. They found that the IAP water vapor measurements were consistently lower (up to $20 \%$ ) than the other techniques used to obtain this parameter.

The RH plot suggests median boundary layer (BL) heights to be $\sim 500 \mathrm{~m}$ a.s.l. for winter and $\sim 1200 \mathrm{~m}$ a.s.l. for summer based on the subjective criterion of a kink in the RH profile (Seibert et al., 2000). Seasonality of BL heights over the SGP site are discussed in Turner et al. (2001) and Della Monache et al. (2004). Turner et al. (2001) suggest mean BL heights to be $700 \mathrm{~m}$ and $1500 \mathrm{~m}$ a.s.l. for winter and summer respectively. They present their findings in terms of mean (as opposed to median) BL height so their results are not directly comparable with these observations or those of Della Monache et al. (2004). Della Monache et al. (2004) find a similar pattern with slightly higher median BL heights - they suggest median winter time boundary layer heights are $\sim 1000 \mathrm{~m}$ a.s.l. and median summertime heights are $\sim 1800 \mathrm{~m}$ a.s.l. while spring and fall BL heights lie in between these values. Della Monache et al. (2004) performed mixing height calculations for the first $2 \mathrm{yr}$ of the airplane flights and investigated how the degree of mixing affects the vertical variation of aerosol optical properties. They found that aerosol properties obtained when the airplane was in the BL were highly correlated with measurements at the surface. Above the BL the aerosol measurements were poorly correlated with surface measurements.

Here we compare AOD and column-average aerosol optical properties $\left(a_{\mathrm{sp}}, \omega_{o}, g\right)$ derived from the 2005-2007 airplane profiles with the same aerosol optical properties determined from AERONET climatologies over the period 19942011. We limit ourselves to the later period of airplane measurements, because these data include super-micrometer particles, have a greater vertical extent, and the absorption Ångström exponent can be used to adjust absorption to different wavelengths. We utilize the entire available time period of AERONET data in order to improve statistics particularly for the single scattering albedo comparison. In 
this set of comparisons the AERONET data remain as reported - the in situ data are adjusted both to ambient conditions (ambient $T, P$ and $\mathrm{RH}$ ) and to match the AERONET wavelengths.

Adjustment of the in situ data to ambient RH is performed using seasonal median fit parameters derived from hygroscopic growth measurements at the SGP surface site. The general set up of the tandem nephelometer humidograph system is described in Sheridan et al. (2001), however the humidity scan timing, location of $T / \mathrm{RH}$ sensors and fitting constraints have evolved over the last decade. Here we use the most recent version of the humidograph data which differs from previously reported values (e.g., Andrews et al., 2004) - the new hygroscopic growth fits tend to result in slightly higher growth than was previously reported. The relatively low ambient median RH values (Fig. 2h) mean that in general the hygroscopic growth adjustment is quite small, e.g., at $60 \%$ RH the annual median growth factor (i.e., scattering increase) is only about 1.3. Increasing the median ambient RH value by $20 \%$ to $72 \% \mathrm{RH}$ (based on the findings by Ferrare et al. (2006) would result in a growth factor of about 1.6.

The observed seasonal variations in AOD derived from the in situ measurements (adjusted to ambient conditions and $500 \mathrm{~nm}$ ) are consistent with seasonality of AERONET AOD at $500 \mathrm{~nm}$ (Fig. 3a) with a peak in summer and minimum in winter. This is the same behavior described by Michalsky et al. (2011) for the SGP site utilizing $16 \mathrm{yr}$ of radiometer data. The median AOD derived from in situ measurements tends to be lower than the AERONET AOD for all seasons except spring where the median values are quite similar. Other direct comparisons of AOD calculated from in situ measurements with remotely sensed AOD (e.g., Schmid et al., 2009 and references within) have also observed that the in situ measurements tend to be lower than the values obtained from remote sensing instruments. The comparison between AERONET AOD and AOD derived from in situ measurements is worst in fall and winter (there is approximately a factor of two difference between AERONET and the in situ measurements). The ambient RH values are quite similar and also quite low for spring and winter, suggesting that the hygroscopic growth adjustment to ambient $\mathrm{RH}$ should also be similar and small for both seasons. The implication is that the hygroscopic growth correction alone is not responsible for the difference observed between AERONET and the in situ measurements. Some other possibilities include: (a) the in situ measurements miss aerosol either above or below the highest flight level; (b) the in situ measurements miss large particles due to the inlet and sample line constraints; (c) the surface hygroscopic growth adjustment is not representative of the hygroscopic growth aloft (i.e., it's too low for most seasons); and/or (d) AERONET sampled statistically different aerosol over the $17 \mathrm{yr}$ period of measurement compared to the 2005-2007 in situ measurements. Esteve et al. (2011) explored several potential reasons for discrepancies between AERONET and in situ aerosol profiles for the airplane that flew over a similar rural site in Illinois, including issues with the hygroscopic growth adjustment, missed aerosol layers and inlet size cut for the in situ measurements. Their work suggests that the primary difference between AERONET and the in situ measurements is due to assumptions involved with the hygroscopic growth measurement, although missing large particles may also play a role. Power et al. (2006) make note of a sampling bias that could affect the comparison here. They compare the frequency of days of given weather type with the frequency of AERONET observations for each weather type at one of the sites in their study. Not surprisingly given the nature of sun photometer measurements, they found that clearer, dryer weather types were over-represented in the AOD data while cloudy humid conditions were underrepresented. In the context of the measurements here, the pilot was not authorized to fly in clouds due to visual flight rules, however he could fly over and under them. Thus, the in situ data statistics include measurements obtained under conditions where AERONET measurements would be unavailable due to the presence of cloud. The possibility of a sample bias influencing the results presented here cannot be eliminated, but given the discrepancies observed in simultaneous in situ and AERONET comparisons (e.g., Andrews et al., 2004; Esteve et al., 2011) such a sample bias is likely a second order effect.

Fig. $3 \mathrm{~b}$ shows the seasonality of single scattering albedo for the AERONET and in situ data. Unfortunately the $\omega_{o}$ retrievals from AERONET are severely limited by the constraint that aerosol optical depth must be greater than 0.4 at $440 \mathrm{~nm}$, such that out of a possible 3818 valid level 2.0 AERONET almucantar inversions between 1994 and 2011, only 128 cases had AOD values above 0.4 for which $\omega_{o}$ values could be retrieved and, of those, only three were for the winter season. The median single scattering albedo values are in the range $0.91-0.97$ with the exception of winter AERONET data. Median values of $\omega_{o}$ for spring and summer are quite similar for AERONET and the in situ data, but the in situ values of $\omega_{o}$ in the fall are quite a bit lower than those reported for AERONET. Sheridan et al. (2001) also report the in situ $\omega_{o}$ measured at the surface is lowest in the fall which they attributed to agricultural field burning near the site. Another thing to note on this plot is that the AERONET $\omega_{o}$ values tend to be higher than those determined from the in situ profiles. One explanation is that the AERONET sun photometer is sampling more scattering aerosol than the airplane - either because large particles that are missed by the in situ inlet or because the hygroscopic growth adjustment to the in situ data is not large enough. A second possibility relates to the systematic variability observed between aerosol loading and single scattering albedo. Single scattering albedo has been shown to be lowest (aerosol is most absorbing) when aerosol loading is lowest (e.g., Andrews et al., 2011; Delene and Ogren, 2002). The AERONET retrievals of $\omega_{o}$ only occur at very high AOD $(>0.4)$, thus they may be biased toward slightly higher $\omega_{o}$ values. 

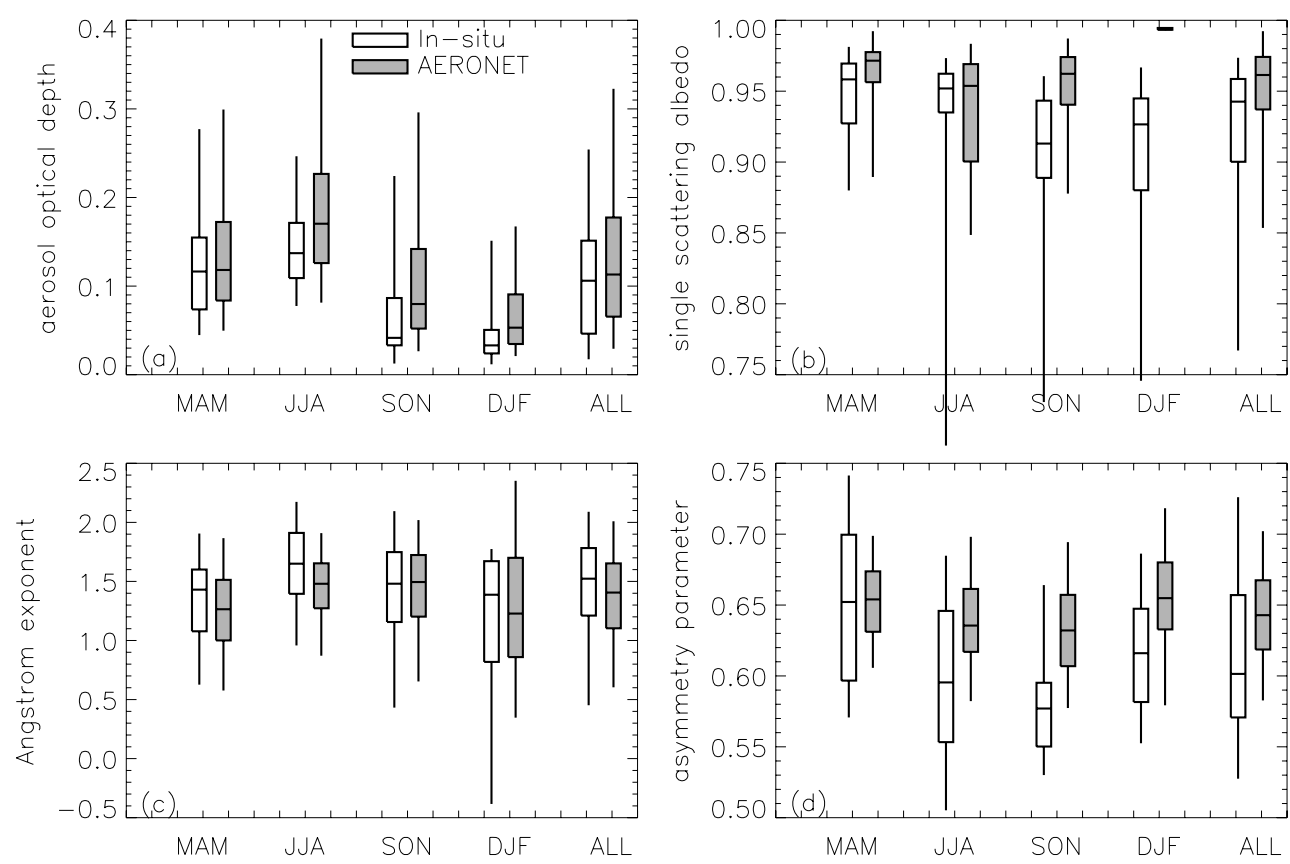

Fig. 3. Comparison of in situ aerosol optical properties adjusted to ambient $T, P$, RH AERONET values (a) aerosol optical depth (at $500 \mathrm{~nm}$ ), (b) single scattering albedo (at $673 \mathrm{~nm}$ ), (c) Ångström exponent (441/673 nm pair) (d) asymmetry parameter (at $673 \mathrm{~nm}$ ). The line in the middle of the box is the median, while the boxes represent the upper and lower quartile and the "whiskers" represent the 5th and 95th percentile.

The comparison of AERONET and in situ values for Ångström exponent (Fig. 3c) and asymmetry parameter (Fig. 3d) show a consistent pattern of smaller particles in the summer and fall and larger particles in the spring and winter. As mentioned previously, this is similar to results published by Michalsky et al. (2010) for the Ångström exponent measured primarily with multi-filter rotating shadowband radiometers (MFRSR) at the SGP site. The seasonal cycle is more obvious in the $673 \mathrm{~nm}$ asymmetry parameter statistics (Fig. 3d). For both quantities the AERONET values tend to suggest larger particles than the column averaged in situ values (i.e., AERONET Ångström exponent is lower than the in situ Ångström exponent and AERONET asymmetry parameter is higher than the in situ asymmetry parameter). The Ångström exponent comparison between AERONET and the in situ profiles is most similar in fall, while the asymmetry parameter comparison is closest in spring and farthest apart in fall.

These comparisons show that there are differences between these two techniques for obtaining column average aerosol optical properties. Every aerosol technique has its advantages and disadvantages. Some are inherent in the instrument design or measurement type (e.g., sun photometers can not measure valid AOD during cloudy periods) and some may be improved upon (assuming the ready availability of funding, time and infrastructure; e.g., payload allowance). Here we present a short list of suggestions for improving the in situ measurements described here. Inlet design and understanding sampling efficiencies as a function of size is critical when comparing different measurements. The inlet change in 2005 made an obvious improvement in our ability to understand the seasonality of the Ångström exponent. Additionally, the Ångström exponent values were used for the adjustment of measured parameters to different wavelengths so having $a_{\text {sp }}$ represent the wider size distribution (not just sub-micron aerosol) was helpful. Further increases in the upper size range of particles sampled could facilitate better comparisons. Another factor that could be improved upon is the determination of the hygroscopic growth effect as a function of altitude. A humidified nephelometer system was deployed on the airplane to provide scattering at a single high humidity $(\sim 85 \%)$ starting in 2003 with the idea of constraining the hygroscopic growth. Unfortunately, due to issues with the nephelometer reliability and design of the humidification control those data are unreliable. Sheridan et al. (2011) present results for a similar system on the airplane operated in Illinois after some problems were resolved. Another limitation of aircraft measurements is that they cannot make measurements all the way down to ground level. Here the profile flights were flown directly over the SGP surface site where there are continuous measurements with which the lowest flight level can be compared. This provided a check on the airplane inlet and instruments and was useful in determining whether there were any consistent differences 

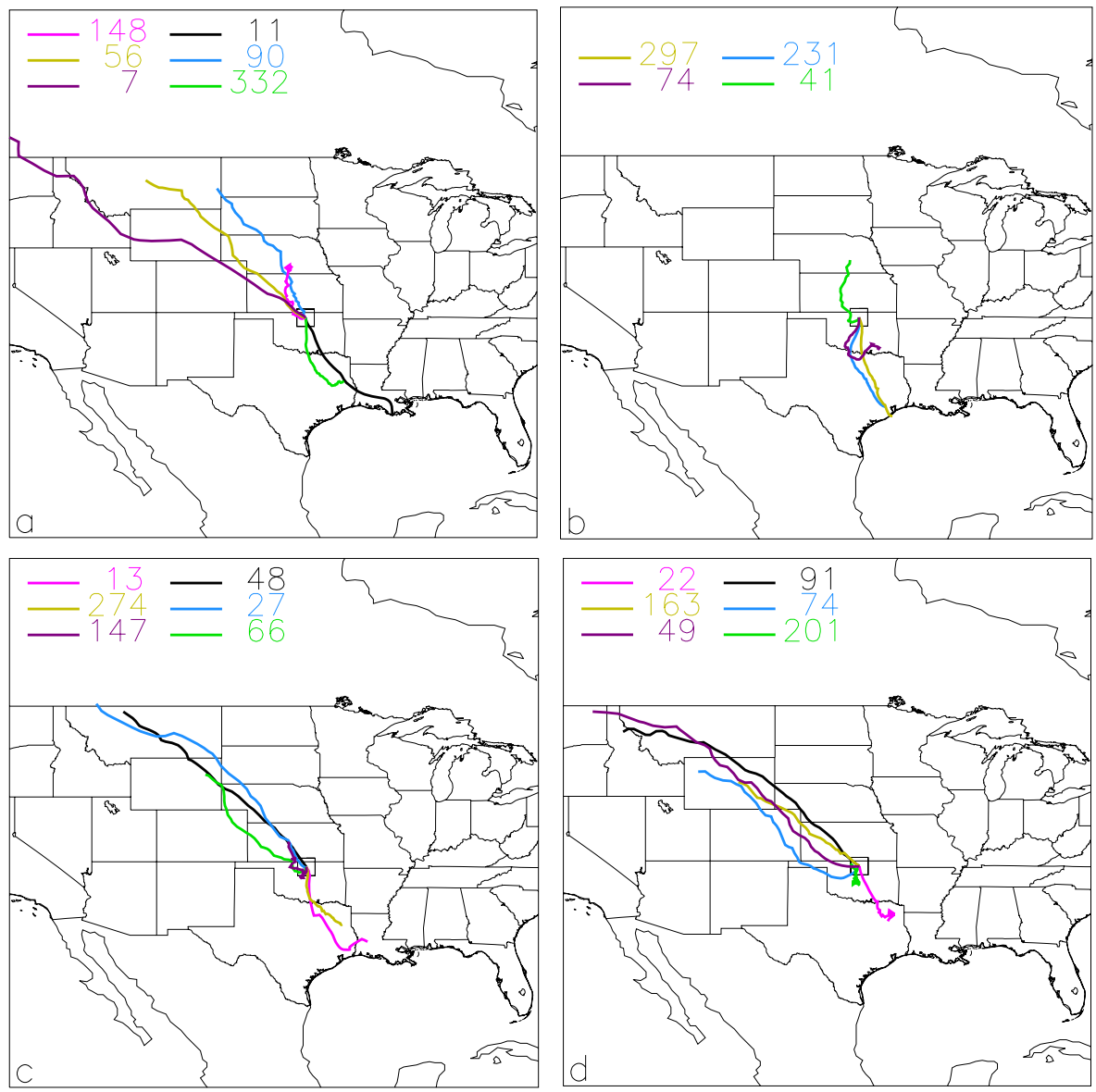

Fig. 4. Plots of air mass back trajectory clusters (cluster medians) arriving at $500 \mathrm{~m}$ to the profile site (indicated by the square) calculated using NOAA/HYSPLIT_4 ${ }^{1}$; (a) Spring (b) Summer (c) Fall (d) Winter. Numbers indicate how many trajectories are in each cluster ${ }^{2}$. A maximum of 6 clusters was allowed. ${ }^{1}$ Trajectories were generated using HYSPLIT_4 downloaded from: www.arl.noaa.gov/ready/hysplit4.html

2 Trajectories that look similar in the x-y plane (e.g., most of the $500 \mathrm{~m}$ winter trajectories) were clustered based on their vertical motion.

between the surface aerosol and the aerosol approximately $150 \mathrm{~m}$ above the surface. Simultaneous flight and surface measurements show excellent agreement between scattering $(550 \mathrm{~nm})$ measured on the lowest level leg (LL) and at the surface $(S)$ suggesting that the airplane and surface site were sampling the same air. For the 2005-2007 time period the relationship was $\sigma_{\mathrm{sp}, \mathrm{LL}}=1.02 \times \sigma_{\mathrm{sp}, S}+3.73\left(R^{2}=0.94\right)$. The relationship for the 2000-2005 scattering (sub1-micron) was $\sigma_{\mathrm{sp}, \mathrm{LL}}=1.04 \times \sigma_{\mathrm{sp}, S}+0.05\left(R^{2}=0.94\right)$.

The NOAA HYSPLIT model (www.arl.noaa.gov/ready/ hysplit4.html; Draxler and Hess, 1998, 1997) was run in batch mode using NCEP reanalysis data to generate two-day back trajectories for every day of the year between 2000 and 2006 for air arriving over SGP at 500, 1500 and $3000 \mathrm{~m}$ a.s.l. These calculated back trajectories were clustered on the basis of latitude, longitude and altitude for each season. A maximum of 6 clusters was allowed. Harris and Kahl (1990) found 6 clusters to be appropriate when they were investigating mass transport climatologies. Here, we found that the resulting trajectory clusters patterns were not significantly different when the number of allowed clusters was changed from 6 to 4,5 or 9 clusters). Trajectories were grouped using $k$-means clustering and the median trajectories are shown for each cluster. This type of clustering minimizes variability within a cluster and maximizes the variability between clusters. There were significant differences in source regions for the different seasons and altitudes (Figs. 4 and 5) and these differences correspond with the seasonal differences observed for aerosol optical properties.

Figure 4 show seasonality of trajectory clusters arriving at SGP at $500 \mathrm{~m}$. Back trajectories arriving at $1500 \mathrm{~m}$ (not shown) were similar to those at $500 \mathrm{~m}$. Approximately $90 \%$ of the $500 \mathrm{~m}$ summertime trajectories (Fig. 4b) arriving originated to the south, with the medians of several of the clusters passing near the Houston and the Dallas-Fort Worth conurbations prior to arriving at SGP. These summertime trajectories tend to be confined within the boundary layer $(<1500 \mathrm{~m})$ and would presumably contain polluted air from the various 

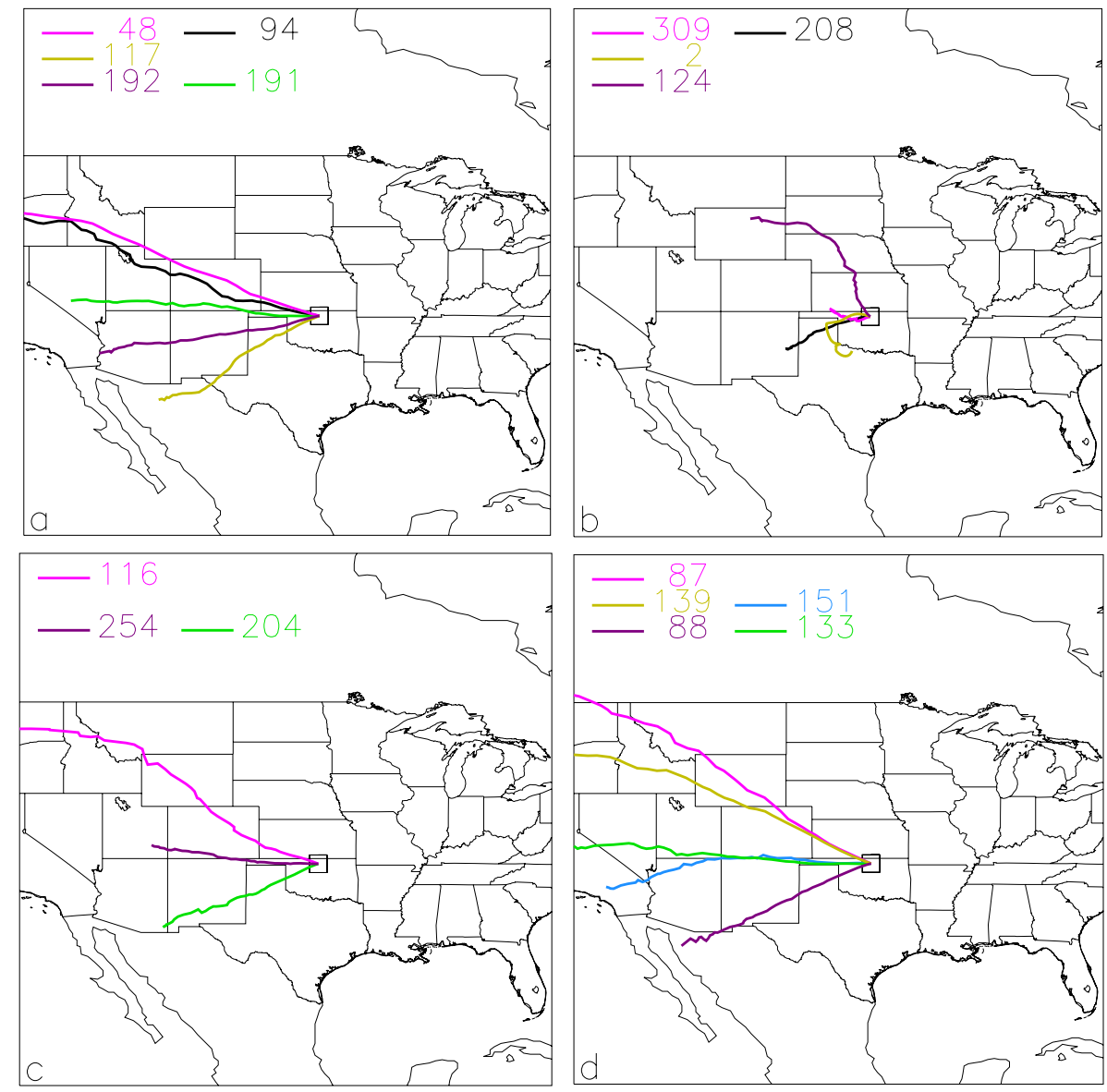

Fig. 5. Plots of air mass back trajectory clusters (cluster medians) arriving at $3000 \mathrm{~m}$ to the profile site (indicated by the square) calculated using NOAA/HYSPLIT_41; (a) Spring (b) Summer (c) Fall (d) Winter. Numbers indicate how many trajectories are in each cluster. A maximum of 6 clusters was allowed. ${ }^{1}$ Trajectories were generated using HYSPLIT_4 downloaded from: www.arl.noaa.gov/ready/hysplit4. html

sources over which they passed. As shown in Fig. 2, the aerosol loading is highest in the summertime and the aerosol is dominated by sub-micron aerosol (high Ångström exponent), both of which would be consistent with the transport of polluted air masses to the site. The aerosol single scattering albedo is the highest (least absorbing) in the summer, consistent with observations of increased sulfate load relative to elemental carbon in the summer (Malm et al., 2004). The higher ambient RH values observed in summer are also consistent with the transport of moist air from low altitudes in the Gulf of Mexico region.

In contrast, $70 \%$ of the wintertime trajectories (Fig. 4d) arriving at $500 \mathrm{~m}$ a.s.l. came from the northwest, passing over sparsely populated regions and descending from altitudes above the wintertime boundary layer on their way to the site. At $500 \mathrm{~m}$, the major difference between the summer and winter aerosol is that the aerosol loading at is lowest in winter.

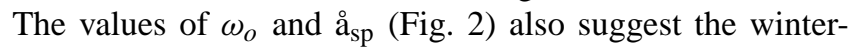
time aerosol is a slightly darker and larger than is observed in summer. This would be most consistent with the transport of a mixture of dust/pollution. The low wintertime ambient RH values are consistent with transport of high altitude arctic air.

Spring and fall trajectories (Fig. $4 \mathrm{a}$ and c) were similar to each other and tended to be split between northwesterly higher altitude trajectories (i.e., winter-like) and southeasterly low altitude trajectories (i.e., summer-like). The intermediate median spring and fall aerosol loading values (scattering and absorption; Fig. 2) and ambient RH are consistent with this mixed flow pattern.

These results are consistent with other analyses of the relationship between aerosol optical properties and atmospheric flow in North America (e.g., Power et al., 2006; Smirnov et al., 1994; Halthore et al., 1992). Power et al. (2006) analyzed spatial and temporal variability of AOD and scattering Ångström exponent as a function of synoptic flow at 27 sites in North America. They found that, in general, colder, drier polar air masses were associated with lower atmospheric turbidity and larger particles while warm, southerly flow coincided with higher aerosol loading and smaller particles. 
They attributed the higher aerosol loading to a variety of factors including differences in sources, surface entrainment of aerosols due to increased convection and enhanced gas to particle due to warmer temperatures. Similarly, Smirnov et al. (1994) and Halthore et al. (1992) found higher AOD values with southerly flow and lower AOD with northerly flow for the individual North American sites they studied.

At $3000 \mathrm{~m}$ the back trajectories reflect the prevailing westerly winds (Fig. 4). Clusters come from NW, W, and SW for all four seasons. The clusters indicate (a) most of the air masses start at $2000 \mathrm{~m}$ or above and (b) they tend to travel over relatively unpolluted/unpopulated regions of the western US. This is consistent with the low amounts of aerosol (as indicated by low scattering coefficients) observed at the higher flight levels. Sources of aerosol arriving at the $3000 \mathrm{~m}$ level in the in situ profiles are difficult to determine. The back trajectory clusters suggest that many of these air masses descend from high altitudes and may have been aloft a long time. The long time aloft provides another explanation for the low aerosol amounts observed at higher altitudes as various removal mechanisms will have opportunity to affect the aerosol properties, i.e., wet scavenging in winter may decrease single scattering albedo. The low Angstrom exponents observed in spring and winter may be related to long range transport of Asian dust - VanCuren et al. (2002) find indicators of Asian dust in high altitude sites in the Rocky Mountain region just to the west of SGP. The spring and winter trajectories suggest another source of coarse aerosol some of the southwesterly trajectories for these seasons originate at lower altitudes (between 1000-1500 m) over the arid desert regions of the US southwest and northern Mexico.

\section{Conclusions}

A temporal analysis of $8 \mathrm{yr}$ of flight data (597 profiles) over the DOE CART site in central Oklahoma was presented. This unique, multi-year collection of aerosol vertical profiles should be useful for validation of chemical transport models. For example, Skeie et al. (2011) utilized this data set, along with other observations, to put in context the ability of their model to predict historical levels of black carbon in the atmosphere and snow.

The profiles of aerosol loading differ both in amount and, to a lesser extent, shape as a function of season. Aerosol loading at the site tends to be highest in summer and lowest in winter, as has been noted previously (e.g., Michalsky et al., 2010; Power et al., 2006; Delene and Ogren, 2002). Aerosol absorption decreases sharply from the surface to approximately $1.5 \mathrm{~km}$ and then is approximately constant or decreases slightly above that. Aerosol scattering decreases with increasing altitude for all seasons but the decrease is sharpest below $1.5 \mathrm{~km}$. In winter the single scattering albedo is lowest above $1.0 \mathrm{~km}$ indicating a change in the relative proportions of scattering and absorption, perhaps due to aerosol processing during transport. The scattering Ångström exponent suggests the largest particles are observed in the winter and spring above $1.5 \mathrm{~km}$, while summer and fall are dominated by small aerosol and the vertical profile is relatively constant with altitude. The seasonality of the Ångström exponent makes clear the importance of utilizing an inlet that passes super-micron aerosol. The absorption Ångström exponent is higher $(\sim 1.3)$ in the springtime consistent with transport of dust and/or biomass burning aerosol. The rest of the year $\stackrel{\circ}{a p}_{\text {ap }}$ is relatively constant at $\sim 1.0 \pm 0.02$, suggesting that the absorption is dominated by elemental carbon.

Comparisons of column-averaged in situ aerosol optical properties with AERONET measurements reveal similar seasonality for AOD, Ångström exponent and asymmetry parameter. The AOD determined from the in situ measurements was significantly lower (factor of two) than the AERONET AOD values for fall and winter, but much closer for spring and summer measurements. The differences between in situ Ångström exponent and asymmetry parameter with those derived from AERONET measurements suggested that the in situ measurements were missing larger particles perhaps due to the inlet cut size, the RH adjustment or perhaps aerosol between the surface and the lowest level flight leg The single scattering albedo values for the two sets of measurements were in the same range (0.91-0.97) but did not show the same temporal pattern, likely due to the constraints imposed by requiring high $\mathrm{AOD}$ values $(\operatorname{AOD}(\lambda=440)>0.4)$ for valid AERONET $\omega_{o}$ retrievals. AERONET climatological values of $\omega_{o}$ tended to be higher than the in situ values. Possible explanations include bias in the AERONET measurements due to the high AOD constraint and/or under-sampling or underadjustment of aerosol scattering due to hygroscopic growth.

Much of the seasonal variability observed in aerosol optical properties is likely due to differences in source regions contributing to air masses arriving at the site. Summertime observations of high levels of aerosol scattering coincide with air being transported within the boundary layer from populous and polluted regions in Texas (Houston and Dallas), while the cleaner conditions (lower scattering) observed in the wintertime correlate with northwesterly air mass back trajectories originating at higher altitudes. These results are in keeping with investigations of changes in aerosol optical properties with synoptic conditions (e.g., Power et al., 2006; Smirnov et al., 1994; Halthore et al., 1992.

Acknowledgements. This research was funded by DOE-ARM. Greenwood Aviation in Ponca City operated the plane and the data set reported here would not have been possible without their dedicated effort. The Cimel Sun-Photometer data were collected by the U.S. Department of Energy as part of the Atmospheric Radiation Measurement Program Climate Research Facility (ACRF) and processed by the National Aeronautics and Space Administration's Aerosol Robotic Network (AERONET). We thank the Brent Holben and Rick Wagener for their effort in establishing and maintaining the SGP AERONET data discussed in this paper 
(AERONET station name for this data set is "Cart Site"). We also thank Anne Jefferson for mentoring the SGP surface humidograph data.

Edited by: T. Kirchstetter

\section{References}

Anderson, T. L. and Ogren, J. A.: Determining aerosol radiative properties using the TSI 3563 integrating nephelometer, Aerosol Sci. Technol., 29, 57-69, 1998.

Anderson, T. L., Covert, D. S., Wheeler, J. D., Harris, J. M., Perry, K. D., Trost, B. E., Jaffe, D. J., and Ogren, J. A.: Aerosol backscatter fraction and single scattering albedo: Measured values and uncertainties at a coastal station in the Pacific Northwest, J. Geophys. Res., 104, 26793-26807, 1999.

Andrews, E., Ogren, J. A., Sheridan, P. J., and Ferrare, R.: Vertical properties of aerosol optical properties at the ARM Southern Great Plains CART site, J. Geophys. Res., 109, D06208, doi:10.1029/2003JD004025, 2004.

Andrews, E., Sheridan, P. J., Fiebig, M., McComiskey, M., Ogren, J. A., Arnott, P., Covert, D., Elleman, R., Gasparini, R., Collins, D., Jonsson, H., Schmid, B., and Wang., J.: Comparison of methods for deriving aerosol asymmetry parameter, J. Geophys. Res., 111, D05S04, doi:10.1029/2004JD005734, 2006.

Augustine, J. A., Hodges, G. B., Dutton, E. G., Michalsky, J. J., and Cornwall, C. R.: An aerosol optical depth climatology for NOAAs national surface radiation budget network (SURFRAD), J. Geophys. Res., 113, D11204, doi:10.1029/2007JD009504, 2008.

Berkowitz, C., Berg, L. K., Yu, X.-Y., Alexander, M. L., Laskin, A., Xie, Y., Jobson, B. T., Andrews, E., and Ogren, J.: The influence of fog and airmass history on aerosol optical, physical and chemical properties at Pt. Reyes National Seashore, Atmos. Environ., 45, 2559-2568, 2011.

Bond, T. C. and Bergstrom, R. W.: Light absorption by carbonaceous particles: An investigative review, Aerosol Sci. Technol., 40, 27-67, 2006.

Bond, T. C., Anderson, T. L., and Campbell, D.: Calibration and intercomperison of filter-based measurements of visible light absorption by aerosols, Aerosol Sci. Tech., 30, 582-600, 1999.

Collaud Coen, M., Weingartner, E., Nyeki, S., Cozic, J., Henning, S., Verheggen, B., Gehrig, R., and Baltensperger, U.: Long-term trend analysis of aerosol variables at the highalpine site Jungfraujoch, J. Geophys. Res., 112, D13213, doi:10.1029/2006JD007995, 2007.

Delene, D. J. and Ogren, J. A.: Variability of aerosol optical properties at four North American surface monitoring sites, J. Atmos. Sci., 59, 1135-1150, 2002.

Delle Monache, L., Perry, K. D., Cederwall, R. T., and Ogren, J. A.: In situ aerosol profiles over the Southern Great Plains cloud and radiation test bed site: 2. Effects of mixing height on aerosol properties, J. Geophys. Res., 109, D06209, doi:10.1029/2003JD004024, 2004.

Draxler, R. R. and Hess, G. D.: Description of the HYSPLIT_4 modeling system, NOAA Technical Memorandum ERL, ARL224, December, 24 pp., 1997.

Draxler, R. R. and Hess, G. D.: An overview of the HYSPLIT_4 modeling system for trajectories, dispersion and deposition,
Aust. Met. Mag., 47, 295-308, 1998.

Dubovik, O. and King, M. D.: A flexible inversion algorithm for retrieval of aerosol optical properties from Sun and sky radiance measurements, J. Geophys. Res., 105, 20673-20696, 2000.

Esteve, A. R., Ogren, J. A., Sheridan, P. J., Andrews, E., Holben, B., and Utrillas, M. P.: Statistical evaluation of aerosol retrievals from AERONET using in-situ aircraft measurements, Atmos. Chem. Phys. Discuss., submitted, 2011.

Fay, M. P. and Proschan, M. A.: Wilcoxon-Mann-Whitney or ttest? On assumptions for hypothesis tests and multiple interpretations of decision rules, Statistics Surveys, 4, 1-39, 2010.

Ferrare, R., Turner, D., Clayton, M., Schmid, B., Redemann, J., Covert, D., Elleman, R., Ogren, J., Andrews, E., Goldsmith, J. E. M, and Jonsson, H.: Evaluation of daytime measurements of aerosols and water vapor made by an operational Raman lidar over the Southern Great Plains, J. Geophys. Res., 111, D05S08, doi:10.1029/2005JD005836, 2006.

Hains, J. C., Taubman, B. F., Thompson, A. M., Stehr, J. W., Marufu, L. T., Doddridge, B. G., and Dickerson, R. R.: Origins of chemical pollution derived from Mid-Atlantic aircraft profiles using a clustering technique, Atmos. Environ., 42, 1727-1741, 2008.

Halthore, R. N., Markham, B. L., Ferrare, R. A., and Aro, T. O.: Aerosol optical properties over the midcontinental United States, J. Geophys. Res., 97, 18769-18778, 1992.

Harris, J. M. and Kahl, J. D.: A descriptive atmospheric transport climatology for the Mauna Loa Observatory using clustered Trajectories, J. Geophys. Res., 95, 13651-13667, 1990.

Haywood, J. M. and Ramaswamy, V.: Global sensitivity studies of the direct radiative forcing due to anthropogenic sulfate and black carbon aerosols, J. Geophys. Res., 103, 6043-6058, 1998.

Huang, L., Gong, S. L., Jia, C. Q., and Lavoué, D.: Importance of deposition processes in simulating the seasonality of the Arctic black carbon aerosol, J. Geophys. Res., 115, D17207, doi:10.1029/2009JD013478, 2010.

Huebert, B. J., Howell, S. G., Covert, D., Bertram, T., Clarke, A., Anderson, J. R., Lafleur, B. G., Seebaugh, W. R., Wilson, J. C., Gesler, D., Blomquist, B., and Fox, J.: PELTI: Measuring the passing efficiency of an airborne low turbulence aerosol inlet, Aerosol Sci. Technol., 38, 803-826, doi:10.1080/027868290500823, 2004.

Husar, R. B., Patterson, D. E., Blumenthal, D. L., White, W. H., and Smith, T. B.: Three dimensional distribution of air pollutants in the Los Angeles Basin, J. Appl. Meteor., 16, 1089-1096, 1977.

Kim, Y. J., Sievering, H., and Boatman, J. F.: Airborne measurement of atmospheric aerosol particles in the lower troposphere over the central United States, J. Geophys. Res., 93, 1263112644, 1988.

Kirchstetter, T. W., Novakov, T., and Hobbs, P. V.: Evidence that the spectral dependence of light absorption by aerosol is affected by organic carbon, J. Geophys. Res., 109, D21208, doi:10.1029/2004JD004999, 2004.

Koch, D., Schulz, M., Kinne, S., McNaughton, C., Spackman, J. R., Balkanski, Y., Bauer, S., Berntsen, T., Bond, T. C., Boucher, O., Chin, M., Clarke, A., De Luca, N., Dentener, F., Diehl, T., Dubovik, O., Easter, R., Fahey, D. W., Feichter, J., Fillmore, D., Freitag, S., Ghan, S., Ginoux, P., Gong, S., Horowitz, L., Iversen, T., Kirkevåg, A., Klimont, Z., Kondo, Y., Krol, M., Liu, X., Miller, R., Montanaro, V., Moteki, N., Myhre, G., Penner, J. E., 
Perlwitz, J., Pitari, G., Reddy, S., Sahu, L., Sakamoto, H., Schuster, G., Schwarz, J. P., Seland, Ø., Stier, P., Takegawa, N., Takemura, T., Textor, C., van Aardenne, J. A., and Zhao, Y.: Evaluation of black carbon estimations in global aerosol models, Atmos. Chem. Phys., 9, 9001-9026, doi:10.5194/acp-9-9001-2009, 2009.

Li, S. M., Macdonald, A. M., Strapp, J. W., Lee, Y. N., and Zhou, X. L.: Chemical and physical characterizations of atmospheric aerosols over southern California, J. Geophys. Res., 102, 212341-21353, 1997.

Liu, H., Pinker, R. T., Chin, M., Holben, B., and Remer, L.: Synthesis of information on aerosol optical properties, J. Geophys. Res., 113, D07206, doi:10.1029/2007JD008735, 2008.

Malm, W. C., Schichtel, B. A., Pitchford, M. L., Ashbaugh, L. L., and Eldred, R. A.: Spatial and monthly trends in speciated fine particle concentration in the United States, J. Geophys. Res., 109, D03306, doi:10.1029/2003JD003739, 2004.

Marcq, S., Laj, P., Roger, J. C., Villani, P., Sellegri, K., Bonasoni, P., Marinoni, A., Cristofanelli, P., Verza, G. P., and Bergin, M.: Aerosol optical properties and radiative forcing in the high Himalaya based on measurements at the Nepal Climate Observatory-Pyramid site (5079 m a.s.1.), Atmos. Chem. Phys., 10, 5859-5872, doi:10.5194/acp-10-5859-2010, 2010. .

McNaughton, C. S., Clarke, A. D., Howell, S. G., Pinkerton, M., Anderson, B., Thornhill, L., Hudgins, C., Winstead, E., Dibb, J. E., Scheuer, E., and Maring, H.: Results from the DC-8 Inlet Characterization Experiment (DICE): Airborne versus surface sampling of mineral dust and sea salt aerosols, Aerosol Sci. Technol., 41, 136-159, 2007.

Michalsky, J., Denn, F., Flynn, C., Hodges, G., Kiedron, P., Koontz, A., Schlemmer, J., and Schwartz, S. E.: Climatology of aerosol optical depth in north-central Oklahoma: 1992-2008, J. Geophys. Res., 115, D07203, doi:10.1029/2009JD012197, 2010.

Moosmüller, H., Chakrabarty, R. K., and Arnott, W. P.: Aerosol light absorption and its measurement: A review, J. Quant. Spectrosc. Radiat. Transfer, 110, 844-878, 2009.

Müller, D., Wandinger, U., Althausen, D., and Fiebig, M.: Comprehensive particle characterization from three-wavelength Ramanlidar observations: Case Study, Appl. Opt., 40, 4863-4869, 2001.

Ogren, J. A.: Comment on "Calibration and Intercomparison of Filter-Based Measurements of Visible Light Absorption by Aerosols", Aerosol Sci. Technol., 44, 589-591, 2010.

O’Neill, N. T., Eck, T. F., Smirnov, A., Holben, B. N., and Thulasiraman, S.: Spectral discrimination of coarse and fine mode optical deph, J. Geophys. Res., 108, 4559, doi:10.1029/2002JD002975, 2003.

Osborne, S. R. and Haywood, J.M.: Aircraft observations of the microphysical and optical properties of major aerosol species, Atmos. Res., 73, 173-201, 2005.

Park, R. J., Jacob, D. J., Chin, M., and Martin, R. V.: Sources of carbonaceous aerosols over the United States and implications for natural visibility, J. Geophys. Res., 108, 4355, doi:10.1029/2002JD003190, 2003.

Power, H. C., Sheridan, S. C., and Senkbeil, J. C.: Synoptic climatological influences on the spatial and temporal variability of aerosols over North America, Int. J. Climatol., 26, 723-741, 2006.
Ramanathan, V., Crutzen, P. J., Kiehl, J. T., and Rosenfeld, D.: Aerosols, Climate and The Hydrological Cycle, Science, 294, 2119-2124, 2001.

Rozwadowska, A.: Influence of aerosol vertical profile variability on retrievals of aerosol optical thickness from NOAA AVHRR measurements in the Baltic region, Oceanologia, 49, 165-184, 2007.

Schmid, B., Flynn, C. J., Newsom, R. K., Turner, D. D., Ferrare, R. A., Clayton, M. F., Andrews, E., Ogren, J. A., Johnson, R. R., Russell, P. B., Gore, W. J., and Dominguez, R.: Validation of aerosol extinction profiles from routine ARM Climate Research Facility measurements, J. Geophys. Res., 114, D22207, doi:10.1029/2009JD012682, 2009.

Seibert, P., Beyrich, F., Gryning, S.-E., Joffre, S., Rasmussen, A., and Tercier, P.: Review and intercomparison of operational methods for the determination of the mixing height, Atmos. Environ., 34, 1001-1027, 2000.

Sellegri, K., Laj, P., Dupuy, R., Legrand, M., Preunkert, S., and Putaud, J.-P.: Size-dependent scavenging efficiencies of multicomponent atmospheric aerosols in clouds, J. Geophys. Res., 108, 4334, doi:10.1029/2002JD002749, 2003.

Sheridan, P. J., Delene, D. J., and Ogren, J. A.: Four years of continuous surface aerosol measurements from the Department of Energy's Atmospheric Radiation Measurement Program Southern Great Plains Cloud and Radiation Testbed site, J. Geophys. Res., 106, 20735-20747, 2001.

Sheridan, P. J., Jefferson, A., and Ogren, J. A.: Spatial variability of submicrometer aerosol radiative properties over the Indian Ocean during INDOEX, J. Geophys. Res., 107, 8011, doi:10.1029/2000JD000166, 2002.

Sheridan, P. J., Andrews, E., Ogren, J. A., and Hoff, R. M.: The NOAA airborne aerosol observatory (AAO): In situ aerosol optical properties, their annual and seasonal variability and comparison with satellite observations over central Illinois, Atmos. Chem. Phys. Discuss., in preparation, 2011.

Skeie, R. B., Berntsen, T., Myhre, G., Pedersen, C. A., Ström, J., Gerland, S., and Ogren, J. A.: Black carbon in the atmosphere and snow, from pre-industrial times until present, Atmos. Chem. Phys., 11, 6809-6836, doi:10.5194/acp-11-6809-2011, 2011.

Smirnov, A., Royer, A, O'Neill, N. T., and Tarussov, A.: Astudy of the link between synoptic air mass type and atmospheric parameters, J. Geophys. Res., 99, 20967-20982, 1994.

Taubman, B. F., Hains, J. C., Thompson, A. M., Marufu, L. T., Doddridge, B. G., Stehr, J. W., Piety, C. A., and Dickerson, R. R.: Aircraft vertical profiles of trace gas and aerosol pollution over the mid-Atlantic United States: Statistics and meteorological cluster analysis, J. Geophys. Res., 111, D10S07, doi:10.1029/2005JD006196, 2006.

Turner, D. D., Ferrare, R. A., and Brasseur, L. A.: Average aerosol extinction and water vapor profiles over the Southern Great Plains, Geophys. Res. Lett., 28, 4441-4444, 2001.

VanCuren, R. and Cahill, T.: Asian aerosols in North America: Frequency and concentration of fine dust, J. Geophys. Res., 107, 4804, doi:10.1029/2002JD002204, 2002.

Veselovskii, I., Kolgotin, A., Muller, D., and Whiteman, D. N.: Information content of multiwavelength lidar data with respect to microphysical particle properties derived from eigenvalue analysis, Appl. Opt., 44, 5292-5303, 2005. 
Vignati, E., Karl, M., Krol, M., Wilson, J., Stier, P., and Cavalli, F.: Sources of uncertainties in modelling black carbon at the global scale, Atmos. Chem. Phys., 10, 2595-2611, doi:10.5194/acp-102595-2010, 2010.
Yu, H., Chin, M., Winker, D. M., Omar, A. H., Liu, Z., Kittaka, C., and Diehl, T.: Global view of aerosol vertical distributions from CALIPSO lidar measurements and GOCART simulations: Regional and seasonal variations, J. Geophys Res., 115, D00H30, doi:10.1029/2009JD013364, 2010. 